\title{
A long-term study on crustacean plankton of a shallow tropical lake: the role of invertebrate predation
}

\author{
Marlene S. ARCIFA, ${ }^{1 *}$ Tânia C. dos SANTOS FERREIRA, ${ }^{1}$ Claudia FILETO, ${ }^{2}$ Maria S. MAIOLI CASTILHO-NOLL, ${ }^{3}$ \\ Taís C. BUNIOTO, ${ }^{1}$ Walter J. MINTO ${ }^{1}$
}

\begin{abstract}
${ }^{1}$ Departamento de Biologia, Universidade de São Paulo, Avenida Bandeirantes 3900, 14040-901 Ribeirão Preto; ${ }^{2}$ Núcleo de Estudos em Ecossistemas Aquáticos (NEEA), Centro de Recursos Hídricos e Ecologia Aplicada (CRHEA), Universidade de São Paulo, Rodovia Domingos Innocentini, km 13, Caixa Postal 292, 13560-970 São Carlos; ${ }^{3}$ Departamento de Zoologia e Botânica, Universidade Estadual Paulista, Rua Cristóvão Colombo 2265, 15054-000 São José do Rio Preto, Brazil

*Corresponding author: marcifa@usp.br
\end{abstract}

\begin{abstract}
The primary factor that governs the size and species composition of zooplankton is still a controversial issue and temperature is considered the main factor responsible for latitudinal differences. In waters with a narrow temperature range, such as in the tropics, predation may be a more important factor. Nearly three decades of intermittent studies of the crustacean plankton in a shallow tropical lake revealed that the main event that led to their restructuring was the appearance of a second predator, the water mite Krendowskia $s p$. The new predator and larvae of the dipteran Chaoborus brasiliensis Theobald exerted a combined, although asymmetrical effect on microcrustaceans. The period when the mite was detected was followed by the restructuring of the crustacean plankton community. Predation by these two invertebrates emerged as the factor responsible for community changes, involving an increased contribution of copepods and decreases in the relative abundance of smaller cladoceran species. In the short term, the mite caused a decrease in species richness and the annual mean instantaneous composition of cladocerans, a predominance of large-sized species (Daphnia ambigua Scourfield and Daphnia gessneri Herbst) and the virtual disappearance of small species (e.g., Bosmina tubicen Brehm). The long-term impact resulted in increased species richness and the dominance of large and medium-sized cladocerans, such as $\mathrm{D}$. gessneri and Ceriodaphnia richardi Sars. The larger body size of three cladocerans, the two Daphnia species and $\mathrm{B}$. tubicen, in the long term, may be a response to the dominant predator, Chaoborus. The seasonal variation in the predator abundance, mainly Chaoborus larvae, allowed the prey to recover during the cool season. The copepods Tropocyclops prasinus meridionalis (Fischer) and Thermocyclops decipiens Kiefer were less affected by predation than the cladocerans; their contribution to the crustacean plankton increased 12-28\% after the mite appeared. The top-down effect on crustacean plankton did not affect the phytoplankton, which remained dominated by chlorophyceans and the nanoplankton fraction before and after the zooplankton community restructuring.
\end{abstract}

Key words: Copepods; cladocerans; chaoborid; water mite; species and size composition.

Received: November 2014. Accepted: June 2015

\section{INTRODUCTION}

Long-term studies are essential for understanding ecological processes such as the influence of stressors and are basic for modeling, but are few in number because of their inherent difficulties, including costs (Jackson and Füreder, 2006; Maberly and Elliott, 2012). In particular, long-term studies of zooplankton can reveal the influence of past factors, including management decisions (Hambright, 2008). Some causes of changes in the zooplankton that are perceptible over a longer period include alterations of abiotic factors or predator invasion (Yan et al., 2008).

The factors that affect the diversity and size of zooplankton species are intriguing issues, but still subject to controversy. From the classic paper by Brooks and Dodson (1965) to recent studies, several factors have been contemplated, and temperature has emerged as the preponderant factor for explaining latitudinal differences in zooplankton body size (Gillooly and Dodson, 2000). Gillooly and Dodson compared more than 1100 lakes lo- cated between $81^{\circ} \mathrm{N}$ and $77^{\circ} \mathrm{S}$ latitude, and found that the size variation of cladoceran species was related to latitude, with smaller sizes in the tropics and the Arctic and a greater difference between the tropics and the temperate zone. According to these authors, the highest mean sizes were observed between $6^{\circ} \mathrm{C}$ and $8^{\circ} \mathrm{C}$, declining at higher or lower temperatures. Havens et al. (2015), comparing 122 lakes located from $6^{\circ}$ to $74^{\circ} \mathrm{N}$ and from $19^{\circ}$ to $21^{\circ} \mathrm{S}$, showed a relationship between size (as weight) of cladocerans and cyclopoid copepods and temperature. In contrast, Iglesias et al. (2011) suggested that predation by fish is the major factor explaining the smaller size of zooplankton in warm lakes. Hart and Bychek (2011), in their extensive review of the many factors that could potentially influence zooplankton size, addressed extrinsic factors such as temperature, food and predation, amongst others, besides intrinsic ones. The authors concluded, however, that although a general pattern may occur, different results can arise from distinct ecosystems. 
Although in these ample compilations on size of microcrustaceans in lakes at different latitudes, temperature has emerged as the most important factor concerning physiological aspects, its influence has been revealed mainly on a macro scale. However, on a smaller scale within a narrower temperature range, such as in the tropics, other factors influence the composition and size structure of zooplankton communities.

Predation affects the size structure of the zooplankton community and the sizes of individual species, with direct and indirect effects on the community (reviews by Zaret, 1980; Kerfoot and Sih, 1987). The relationships between predators and zooplankton composition were summarized in a conceptual model, showing the strength of the different predatory actions (Lampert and Sommer, 2007, Fig. 6.33 , p. 180). The species' sizes in a zooplankton community subjected to different predatory forces could be predicted, depending on the interaction between visual and non-visual predators in the ecosystem. Thus, the larger species would be visually preyed on and the small- and medium-sized ones would be preyed on by invertebrates, which are oriented by tactile stimuli. However, it is not always easy to distinguish clear patterns and zooplankton communities are generally composed of medium-sized species (Hart and Bychek, 2011). Furthermore, visual predation is not always determinant in controlling zooplankton, since tactile predation can play the main role (Blumenshine and Hambright, 2003). In some temperate lakes and ponds, the main controlling agent of zooplankton may be primary productivity (Finlay et al., 2007) or temperature and $\mathrm{pH}$ (Steiner, 2004), rather than predation. Saunders et al. (1999), in their conceptual model of the influence of factors on planktonic herbivores (Fig. 10), highlighted food, temperature, and predation as major forces in lakes. However, the authors showed that the predation pressure differs in lakes at different latitudes, with a longer action period in tropical and subtropical lakes. Therefore, the predation pressure in warm lakes is stronger than in their temperate counterparts.

Planktivorous fish commonly occur in the limnetic zone of temperate lakes, particularly in eutrophic systems (Jeppesen et al., 2003). In contrast, omnivory predominates in tropical and subtropical lakes (Lazzaro, 1997; Jeppesen et al., 2007; González-Bergonzoni et al., 2012), except in some high-altitude tropical lakes in Ethiopia (Vijverberg et al., 2014). In addition, young and smallsized fish species that could potentially exploit zooplankton are mostly associated with the littoral zone in warm lakes (Fernando, 1994; Arcifa and Northcote, 1997; Meschiatti and Arcifa, 2002; Agostinho et al., 2003; Teixeira-de Mello et al., 2009), and are, therefore, segregated from the limnetic zooplankton. Predatory invertebrates can exert greater pressure on zooplankton if they are not strongly controlled by fish (Lampert and Sommer, 2007; Pinto-Coelho et al., 2008). However, when other factors, such as turbidity and dissolved oxygen, reduce the spatial overlap between fish and Chaoborus, prey consumption by the dipteran larvae can exceed that of fish, becoming the major predatory force even when planktivores are abundant (Liljendahl-Nurminen et al., 2003).

Lake Monte Alegre is no exception, amongst warm lowland lakes, to the pattern of relatively low predation pressure on zooplankton exerted by visual predators. The only planktivore is represented by adults of the exotic cichlid Tilapia rendalli Boulenger, which are pump filterfeeders that consume mostly phytoplankton (Arcifa and Meschiatti, 1993, 1996). Larvae of the dipteran Chaoborus brasiliensis Theobald were earlier identified as the main predators in this lake (Arcifa et al., 1992), but in 1998-99 another invertebrate predator of zooplankton was detected, the water mite Krendowskia sp. (Cassano et al., 2002).

We investigated the species composition and size structure of zooplankton in Lake Monte Alegre, in intermittent studies during nearly three decades, addressing several issues: I. whether observed long-term changes in species composition and size of crustacean plankton were related to the detection of a new invertebrate predator, a water mite; II. predation by invertebrates is the main factor structuring the community; III. predation pressure varies seasonally, inducing higher prey abundance in the cool season, when predators are less abundant; IV. predation pressure is stronger on cladocerans than on copepods; $\mathrm{V}$. the effects of the restructured microcrustacean community on the phytoplankton composition.

\section{METHODS}

\section{Study area}

Lake Monte Alegre $\left(21^{\circ} 10^{\prime} 04^{\prime \prime} \mathrm{S}, 47^{\circ} 51^{\prime} 28^{\prime \prime} \mathrm{W}\right)$ is a small, shallow, eutrophic reservoir located in southeastern Brazil. It belongs to the warm discontinuous polymictic type (area: $7 \mathrm{ha} ; \mathrm{Z}_{\text {max }}: 5 \mathrm{~m}$; mean depth: $2.9 \mathrm{~m}$; altitude $500 \mathrm{~m}$ asl). The reservoir was closed in 1942 , by damming Laureano Creek in the Pardo River basin. In the warm season its stratification is relatively stable, leading to oxygen depletion near the bottom in the deepest part of the limnetic zone (Arcifa et al., 1990). Although Monte Alegre is a reservoir, it functions similarly to a natural shallow lake, due to certain features such as lack of manipulation of the dam and the outlet at the surface, and the relatively long retention time ( $c a .45$ days) for its dimensions. The regional climate is tropical, with a dry winter - Köppen Aw (Alvares et al., 2013) and a defined cool-dry season (May-September) and a warm-wet one (October-April) (Nimer, 1989).

In 1998-99, the fish fauna of the lake consisted of 9 species, mainly small- and medium-sized cichlids and characiforms, most of them inhabitants of the littoral zone and macrophytes (Meschiatti and Arcifa, 2002). The main food item of the fish fauna, in 1988-89 and 1998-99, was aquatic insects, with zooplankton representing a minor dietary item (Arcifa and Meschiatti, 1993; Meschiatti and 
Arcifa, 2002). The planktivorous fish $T$. rendalli is diurnal, limnetic, not abundant, and did not cause a decrease in plankton abundance in mesocosm experiments (Silva et al., 2014).

Larvae of $C$. brasiliensis (max length $\sim 6 \mathrm{~mm}$ ) are omnivores, III and IV instars feeding mostly on microcrustaceans and dinoflagellates (Arcifa, 2000; Castilho-Noll and Arcifa, 2007a). The larvae are more abundant in the benthos of the limnetic zone than in the littoral zone (Cleto-Filho and Arcifa, 2006), as well as in the water column of the limnetic zone. The water mite Krendowskia sp. (max length $\sim 1.1 \mathrm{~mm}$ ) is also a limnetic dweller (Arcifa et al., 2013), but its densities are lower than those of Chaoborus larvae.

\section{Sampling}

Zooplankton and invertebrate predators were sampled in the periods 1985-86, 1988-89, 1998-99, 2001-02, 200607 , and 2011-12. The sampling frequency was weekly (1985-86, 2011-12), biweekly (1988-89, 1998-99, 200607) and monthly (2001-02).

The organisms were always collected in the deepest area of the lake $(5 \mathrm{~m})$, which is the best site for planktonic organisms and representative of this small lake. They were collected vertically in the water column, with a 70 $\mu \mathrm{m}$-mesh net, in the first two periods (1985-88, 1988-89, 2 replicates of $271 \mathrm{~L}$ each) and with a pump (Jabsco, model 34600-0000), delivering $30 \mathrm{~L} \mathrm{~min}^{-1}$, in the remaining periods (1 sample of $120 \mathrm{~L}$ in 1998-99; 1 sample of $150 \mathrm{~L}$ in 2006-07; 2 replicates in 2001-02 and 3 in 20112012, filtering $150 \mathrm{~L}$ each). The invertebrate predators were not counted in all periods, but their occurrence was always recorded. At least three sub-samples taken with Stempel pipettes were counted on a gridded chamber under a stereomicroscope. Samples with low densities, larvae of C. brasiliensis, and the mite Krendowskia sp. were counted completely. Whenever possible, 30 of the standard size (largest adult individuals) of the most abundant cladoceran species were measured in samples in some of the study periods.

At the same station, phytoplankton samples were taken biweekly in the euphotic zone in 1988-89, and weekly in 2011 (April through June). Sedimented samples were counted under a Zeiss inverted microscope, according to Utermöhl (1958), in random fields (Uehlinger, 1964). Temperature, electrical conductivity (at $\left.25^{\circ} \mathrm{C}\right), \mathrm{pH}$, dissolved oxygen (DO) and chlorophyll- $a$ were measured in all periods. In the first two periods, the temperature was measured with a thermometer attached to a Ruttner bottle; the electrical conductivity and $\mathrm{pH}$ with the Metrohm E 382 and Orion (model 301) probes, respectively; and DO by the Winkler method. From 1998 onwards, Yellow Springs Inc. probes were used, models 95 (DO and temperature), $60(\mathrm{pH})$ and 30 (conductivity). Chlorophyll- $a$ was analysed by the method of Jeffrey and Humphrey
(1975), except in 1998-99, when the method of Lorenzen (1967) was used. The analyses of Total Nitrogen (TN) and Total Phosphorus (TP) followed the methodology of APHA (1995) and were performed for unfiltered water samples collected in 2011-12.

The data base of this study originates from articles covering the periods 1985-86 and 1988-99 (Arcifa et al., 1992, 1998), and unpublished data from theses in the other periods. This data set was re-analysed to provide a long-term overview.

One-way ANOVA (Post-hoc Tukey test) was used for evaluating differences in mean densities of copepods and chaoborid larvae in the different periods. The differences for cladocerans were assessed by the Kruskal-Wallis test. Mann-Whitney (Statistica, StatSoft) was applied to test differences in mean densities of prey and predators between seasons and the size of cladocerans in the different periods. The Multi-Response Permutation Procedure (MRPP) was used to test the significance of the Detrended Correspondence Analysis (DCA). The factors used in the DCA were the annual mean density for each species in each period.

\section{RESULTS}

Abiotic features, including $\mathrm{pH}$, electrical conductivity and DO were conservative during the nearly three decades of study. Their values in the surface layers, throughout the year, were 6-8 $(\mathrm{pH}), 50-80 \mu \mathrm{S} \mathrm{cm}^{-1}$ (conductivity) and 80$120 \%$ oxygen saturation (DO). Concentrations of TN and $\mathrm{TP}$, ranging from $229-961 \mu \mathrm{g} \mathrm{L}^{-1}$ and $22-643 \mu \mathrm{g} \mathrm{L}^{-1}$, respectively, were obtained in the surface layers, in 201112. Mean concentrations of chlorophyll- $a$ showed interannual variations, with lower levels in 1998-99 and 2006-07 (Tab. 1). However, the lower concentrations in 1998-99, compared to most periods, may also be related to the method used (Lorenzen, 1967), which only considers active chlorophyll- $a$. The minimum temperatures in the cool season and the maximum temperatures in the warm season varied little across periods (Tab. 1).

Nine species of planktonic cladocerans and two cyclopoid copepods occurred in the course of the study period (Tab. 2). The 1998-99 period proved to be critical for the planktonic crustacean community and hereafter is termed the key period. This period was marked by the de-

Tab. 1. Annual mean concentrations ( \pm SE) of chlorophyll- $a$ and minimum and maximum temperatures during the study periods.

\begin{tabular}{ccc} 
Period & Chlorophyll- $a\left(\right.$ Hg L $\left.^{-1}\right)$ & Temperature $\left({ }^{\circ} \mathrm{C}\right)$ \\
\hline $1985-86$ & $22.91 \pm 1.38$ & $18-31$ \\
$1988-89$ & $18.11 \pm 0.70$ & $18-29$ \\
\hline $1998-99$ & $9.07 \pm 0.90$ & $20-31$ \\
$2001-02$ & $15.01 \pm 2.33$ & $20-29$ \\
\hline $2006-07$ & $8.82 \pm 0.62$ & $19.5-29$ \\
$2011-12$ & $21.37 \pm 1.66$ & $19-30$ \\
\hline
\end{tabular}


tection of the mite Krendowskia sp., which was virtually absent from the samples in previous periods. Ordering the periods and species revealed a clear and significant grouping $(\mathrm{A}=0.1163, \mathrm{P}=0.03)$, and the key period (1998-99) was essential in separating a previous phase (1985-86 and 1988-89) from a later one (2001-02, 2006-07, and 201112) after the mite detection (Fig. 1). We do not know exactly when the mite appeared, since a decade elapsed between the previous sampling period (1988-89) and its appearance in significant numbers in 1998-99. However, based on the clear differences between the two groups of periods, before and after the mite was detected, we presume that it appeared or increased at some time close to the key period.

Some cladoceran species, such as Daphnia gessneri Herbst and Bosmina tubicen Brehm, underwent a significant increase in mean maximum size from the first to the last study period (Tab. 2). In two periods (1998-99 and 2011-12) the mean size of Daphnia ambigua Scourfield was larger than $1 \mathrm{~mm}$, exceeding that of 1985-86. In nu-
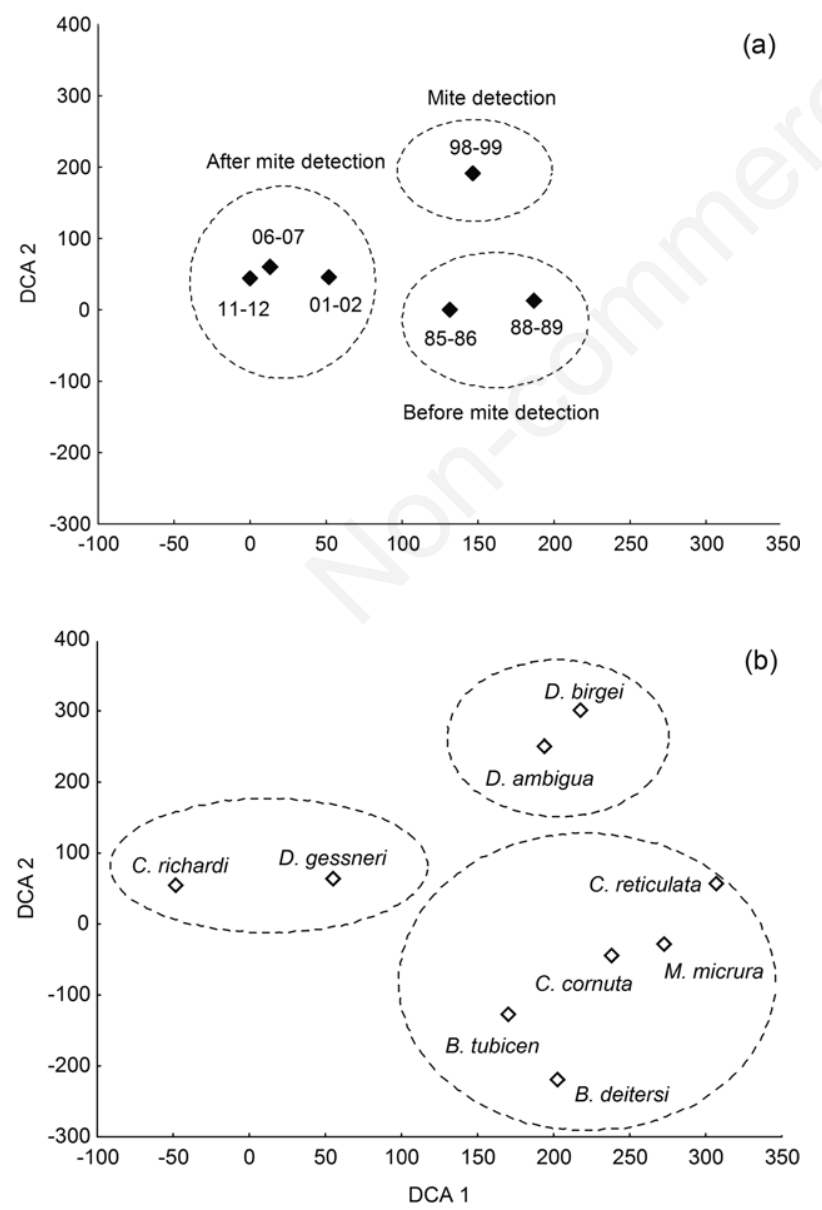

Fig. 1. Detrended Correspondence Analysis (DCA) and the groupings of periods (a) and species of cladocerans in the periods (b). merical terms, copepods always dominated in relation to cladocerans, contributing ca. $67 \%$ before the key period, and $77-95 \%$ afterwards (Fig. 2). The number of cladoceran species, 5 to 7, was reduced to 3 in the key period (Fig. 3). The mean annual instantaneous composition of cladocerans was 4-5 species, and decreased to 2.4 in the key period.

Given their higher species richness, cladocerans were more appropriate for comparing the periods than were the copepods. Starting from 9 species in 1985-86, the species richness subsequently declined, with the virtual disappearance of Bosminopsis deitersi Brehm, Ceriodaphnia reticulata (Jurine) and Moina minuta Hansen (Fig. 4). D. gessneri was a constant species that contributed substantially to the cladoceran composition. Ceriodaphnia richardi Sars, on the other hand, was detected from 2001-02 onwards and continued to increase, reaching its highest value in the last period. The most remarkable event was the disappearance of the class of small-sized cladocerans and a clear dominance of the largest species in the key period (Fig. 5). The contribution of the small-sized class declined from $47 \%$ before the key period to $0.3-16 \%$ afterwards. The contribution of the medium- and large-sized classes increased after the key period, except in the last period (2011-12), when a medium-sized species dominated.

Annual mean densities of cladocerans varied amongst periods (Kruskal-Wallis test, $\mathrm{H}=34.6, \mathrm{P}=0.000$ ); one period (2006-07) showed a significantly higher mean density $\left(70\right.$ ind $\left.\mathrm{L}^{-1}\right)$. Cladocerans showed a trend towards a higher mean density in the cool season than in the warm one, with significant differences in the periods 1985-86 $(\mathrm{P}=0.001), 2001-02(\mathrm{P}=0.01)$ and 2011-12 $(\mathrm{P}=0.001)$ (Fig. 6a). Annual mean densities of copepods did not change significantly before and during the key period (1985-86, 1988-89, 1998-98), but showed a highly significant increase after the key period (2001 through 2012) (One-way ANOVA, F=221.05, $\mathrm{P}<0.001$ ). Mean density of copepods showed no clear seasonal trend except in

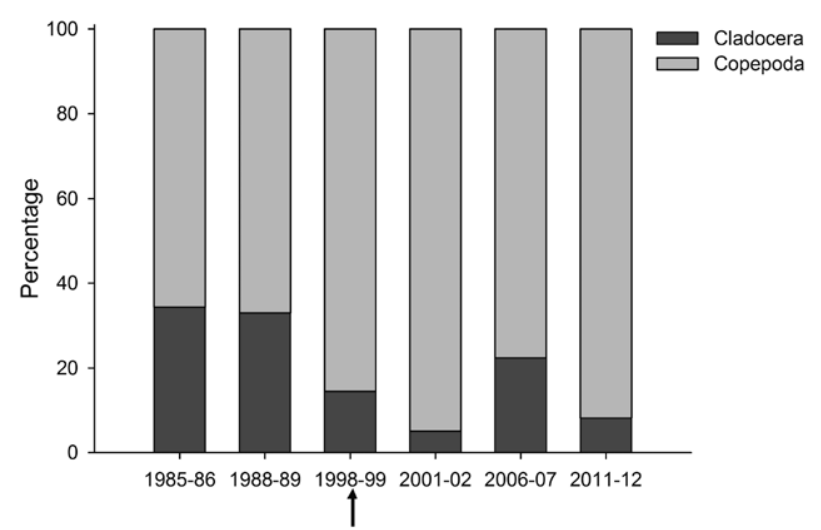

Fig. 2. Relative abundance of groups of microcrustaceans in the different periods. Arrow indicates the key period (1998-99). 
2006-07, when the density increased in the cool season $(\mathrm{P}=0.001)$ (Fig. 6b).

The mean densities of Chaoborus larvae fluctuated significantly amongst periods (One-way ANOVA, $\mathrm{F}=365.5$, $\mathrm{P}<0.001)$. There were no significant differences amongst the 1985-86, 1998-99 and 2006-07 periods, but densities were significantly higher in 2001-02 (2.3 ind $\left.\mathrm{L}^{-1}\right)$ and 2011$12\left(0.8\right.$ ind $\left.\mathrm{L}^{-1}\right)$. A trend towards greater abundance of chaoborid larvae in the warm season was significant for three periods (1985-86, $\mathrm{P}=0.006 ; 2001-02, \mathrm{P}=0.05 ; 2011-12$, $\mathrm{P}=0.05$ ) (Fig. 7). The same tendency was not found for mites, except in 2011-12 ( $\mathrm{P}=0.001)$.

The phytoplankton was dominated by chlorophyceans

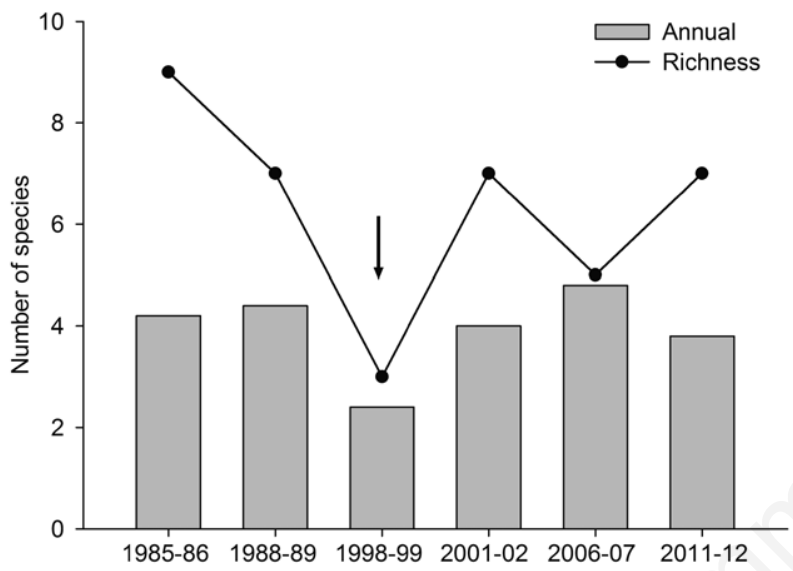

Fig. 3. Species richness of cladocerans and the mean annual instantaneous composition of species in the different periods. Arrow indicates the key period (1998-99). before and after the key period, with cyanobacteria contributing 18 and $9.6 \%$, respectively in 1988-89 and 2011 (Fig. 8). The phytoplankton fractions fluctuated, including seasonally, but on average the nanoplankton $(\leq 20 \mu \mathrm{m})$ predominated overall.

\section{DISCUSSION}

The data showed no evidence of relationships between the changes in the structure of the microcrustacean community and the temperature and food in Lake Monte Alegre, in the long-term. In experiments, a lower temperature influenced several life-table parameters of three species

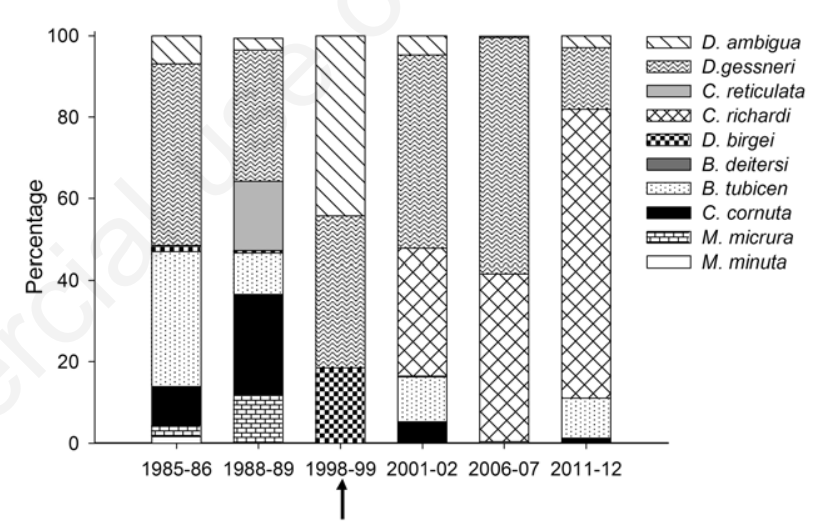

Fig. 4. Relative abundance of cladoceran species in the different periods. Arrow indicates the key period (1998-99).

Tab. 2. Species and maximum length of microcrustaceans.

\begin{tabular}{|c|c|c|}
\hline & Size \pm SD $(\mathrm{mm})$ & Size \pm SD $(\mathrm{mm})$ \\
\hline \multicolumn{3}{|l|}{ Cladocera } \\
\hline \multicolumn{3}{|l|}{ Large species } \\
\hline Daphnia ambigua Scourfield & $0.86 \pm 0.05$ & $1.03 \pm 0.02$ \\
\hline Daphnia gessneri Herbst & $1.07 \pm 0.07$ & $1.22 \pm 0.01^{* *}$ \\
\hline \multicolumn{3}{|l|}{ Medium-sized species } \\
\hline Ceriodaphnia reticulata (Jurine) & $0.70 \pm 0.04$ & Absent \\
\hline Ceriodaphnia richardi Sars & Absent & $0.70 \pm 0.00$ \\
\hline Diaphanosoma birgei Kŏrínek & $0.61 \pm 0.02$ & Absent \\
\hline \multicolumn{3}{|l|}{ Small species } \\
\hline Bosminopsis deitersi Richard & $0.32 \pm 0.05$ & Absent \\
\hline Bosmina tubicen Brehm & $0.41 \pm 0.06$ & $0.58 \pm 0.02^{*}$ \\
\hline Ceriodaphnia cornuta Sars & $0.46 \pm 0.03$ & $0.49 \pm 0.01$ \\
\hline Moina micrura Kurz & $0.48 \pm 0.04$ & Absent \\
\hline Moina minuta Hansen & $0.45 \pm 0.04$ & Absent \\
\hline \multicolumn{3}{|l|}{ Copepoda } \\
\hline Thermocyclops decipiens Kiefer & $0.74 \pm 0.03$ & No data \\
\hline Tropocyclops prasinus meridionalis (Fischer) & $0.49 \pm 0.07$ & No data \\
\hline
\end{tabular}

Significant difference in length: ${ }^{*} P=0.01 ;{ }^{* *} P<0.001$. 
of cladocerans from the lake, D. ambigua, D. gessneri and M. micrura, which showed significantly lower population growth rates at $19^{\circ} \mathrm{C}$ (winter temperature) than at $27^{\circ} \mathrm{C}$ (mean summer temperature) (Bunioto and Arcifa, 2007). However, although temperature could occasionally cause a decline in densities of cladocerans during the cool season, it is an unlikely explanation for the observed longterm changes, since the lowest winter temperatures were similar amongst the periods. Although in this lake food quantity and quality can be limiting during the cool season (Ferrão-Filho et al., 2003, 2005), there was no indication of a long-term influence on the microcrustaceans. Finlay et al. (2007), studying several temperate lakes, concluded that zooplankton were controlled mainly by primary productivity (bottom-up) and not by predators (top-down). However, the seasonal increase in food availability in Lake Monte Alegre, with higher primary productivity of the phytoplankton (1998-99; Feresin et al., 2010) or biomass (2011-12; Ferreira, 2013) in the warm season, did not result in corresponding increases of herbivorous microcrustaceans, particularly cladocerans (Fig. 6a).

The detection of the mite in the lake was the most striking event over 27 years, and its presence apparently changed both the species composition and the size and abundance of some microcrustacean species. Although members of its genus are considered benthic (Fernández and Fossati-Gaschignard, 2011), in this lake Krendowskia sp. was collected from both the bottom sediments and in the water column of the limnetic zone. The mite performed nocturnal vertical migration in 2001-02, when most individuals disappeared from the water column during the day. Therefore, in addition to the direct effect of predation by mites on the community restructuring, an indirect effect cannot be ruled out, which is the change in the migratory behaviour of Chaoborus, one of their prey (Cassano et al.,

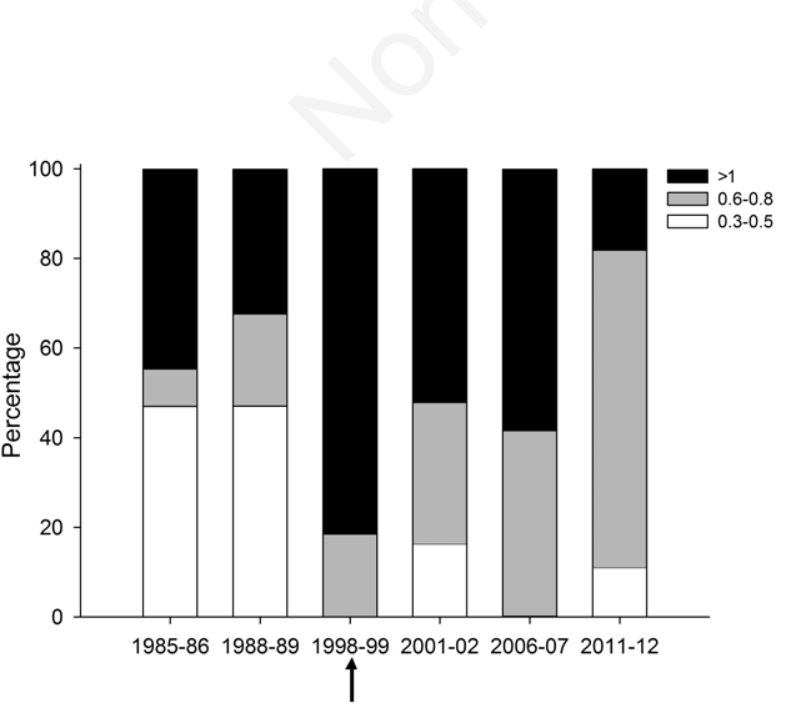

Fig. 5. Relative composition of size classes ( $\mathrm{mm}$ ) of cladoceran species in the different periods. Arrow indicates the key period (1998-99).
2002). The instar IV of Chaoborus, which migrated to the bottom sediments during the day, before the appearance of the mite (Arcifa, 1997), occupied the water column more after the key period, probably as a strategy to decrease overlap with mites at the bottom. This change in behaviour may have resulted in increased predation pressure by chaoborids on microcrustaceans, on a diel cycle.

Several studies have demonstrated the influence of mites on zooplankton species, depending on their density. Half of the mortality of Bosmina could be related to mite densities of 200-300 ind $\mathrm{m}^{-3}$ (Balseiro, 1992). Death rates of Daphnia and densities of mites were correlated, when the mites reached 400 ind $\mathrm{m}^{-3}$ (Matveev et al., 1989). In the key period in Lake Monte Alegre, the mites reached maximum densities of 312 ind $\mathrm{m}^{-3}$, and in the summer of 1999, aggregates of 1800-2000 ind $\mathrm{m}^{-3}$ were recorded at night (Perticarrari, 2000).

Independently of species and their sizes, water mites prefer small- and medium-sized cladocerans, as reported by Gliwicz and Biesiadka (1975) and Riessen (1982); most of the species studied are larger than Krendowskia
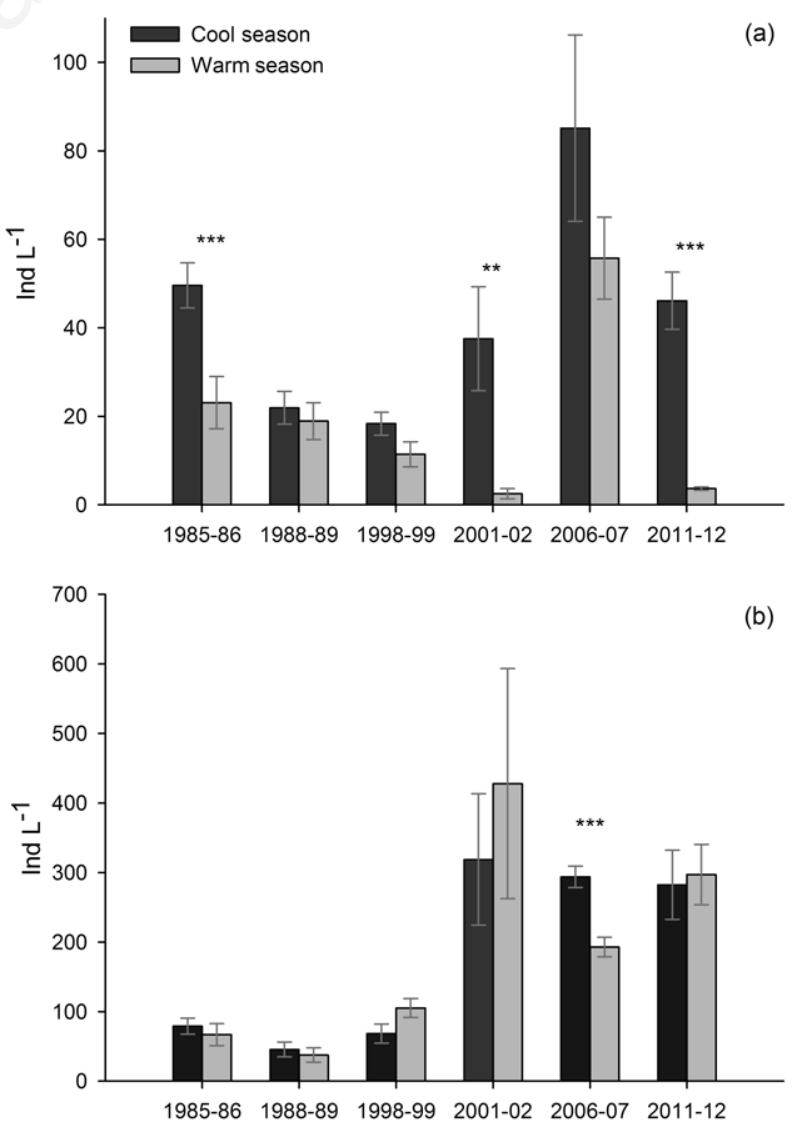

Fig. 6. Mean densities of cladocerans (a) and copepods (b) in the cool and warm seasons, in the different periods. Significant differences between seasons: ${ }^{* *} \mathrm{P}=0.01 ;{ }^{* * *} \mathrm{P}=0.001$. 
sp. Adults of the mite Piona constricta (Wolcott) showed the following ranked prey preference: Bosmina $>$ Daphnia, Ceriodaphnia $>$ Chydorus $>$ Diaphanosoma, Diaptomus > Mesocyclops (Riessen, 1982), i.e., a small cladoceran species was the favourite prey. Riessen (1982) found that the ingestion time of $P$. constricta is proportional to prey size, from 3-5 min for Bosmina and young Ceriodaphnia to 35-40 min for the large Daphnia pulex Leydig. B. tubicen is the preferred prey of Chaoborus larvae in Lake Monte Alegre (Arcifa, 2000; Castilho-Noll and Arcifa, 2007a), and is possibly also preyed upon by mites. Its virtual disappearance from the limnetic zone in the key period was attributed to the pressure of the two invertebrate predators (Cassano et al., 2002). D. gessneri was preyed upon in laboratory experiments (Cassano et al., 2002), but in mesocosm experiments there was no evidence of a negative effect of the mite on its population dynamics (Castilho-Noll and Arcifa, 2007b), which may have contributed to its persistence in the lake. The presence of multiple predators can increase or decrease the impact on their prey (review by Sih et al., 1998). The mite Piona carnea (Koch) exerted a negative effect on $D$. pulex, which depended on the system productivity and the mite density (Stegen and Black, 2011); however, predation by the mite and by Chaoborus americanus (Johannsen) had no combined effect, decreasing the risk for prey in their joint action. This conclusion is not supported by our results regarding the cladocerans in Lake Monte Alegre, where pressure by both predators decreased cladoceran abundance and species richness.

The increased contribution of copepods to the crustacean community after the key period is an indication that this group is subject to a lower negative impact of predation by invertebrates. Copepods are also resistant to predation by fish (Jeppesen et al., 2001) and were preyed on by Chaoborus flavicans (Meigen) when cladocerans were scarce (Jäger et al., 2011). In Lake Monte Alegre, Chaoborus consumed proportionately more copepods after the decline of the favourite prey Bosmina tubicen (Perticarrari et al., 2004). Researchers studying Lake Monte Alegre have suggested that copepods are less sensitive to the effects of predation by invertebrates due to reproductive traits, such as greater fertility and more rapid development of eggs (Castilho-Noll and Arcifa, 2007b), and behavioural, such as reverse vertical migration (Perticarrari et al., 2004; Minto et al., 2010). The population dynamics of copepods was not affected by Chaoborus larvae in mesocosms (Castilho-Noll and Arcifa, 2007b), and they are not preyed on by the mite (Cassano et al., 2002). Marine copepods detect predators by mechanoreception, and their myelinated nerves allow rapid conduction of impulses and consequent rapid escape movements (Buskey et al., 2012). Some copepods, such as Cyclops scutifer Sars, can escape a predator at a speed of $50 \mathrm{~cm} \mathrm{~s}^{-1}$ (Strickler, 1975), an incredible velocity compared to cladocerans. They seem to detect chemical cues from predators, amongst other skills to decrease predation risk (Heuschele and Selander, 2014). Sensitivity to kairomones released by Chaoborus was suggested to explain the reverse migration of copepods, from Lake Monte Alegre, in experiments (Minto et al., 2010). This reverse-migration behaviour appeared after Chaoborus began to predate more intensely on copepods (Perticarrari et al., 2004). Cladocerans from the lake, however, are more susceptible than copepods to predation by invertebrates (Cassano et al., 2002, Castilho-Noll and Arcifa, 2007a,b). Apparently, D. gessneri is less sensitive to kairomones than copepods, and its diel vertical migration was related to physical contact with Chaoborus (Minto et al., 2010). The small species $B$. tubicen, which comprised $53-56 \%$ of the diet of Chaoborus instars III and IV in the first period (19851986; Arcifa, 2000), disappeared from their diet in the key period (Castilho-Noll and Arcifa, 2007a), when it was also absent in the limnetic samples.

According to pioneer studies (Brooks and Dodson, 1965), small-sized zooplankton would dominate when
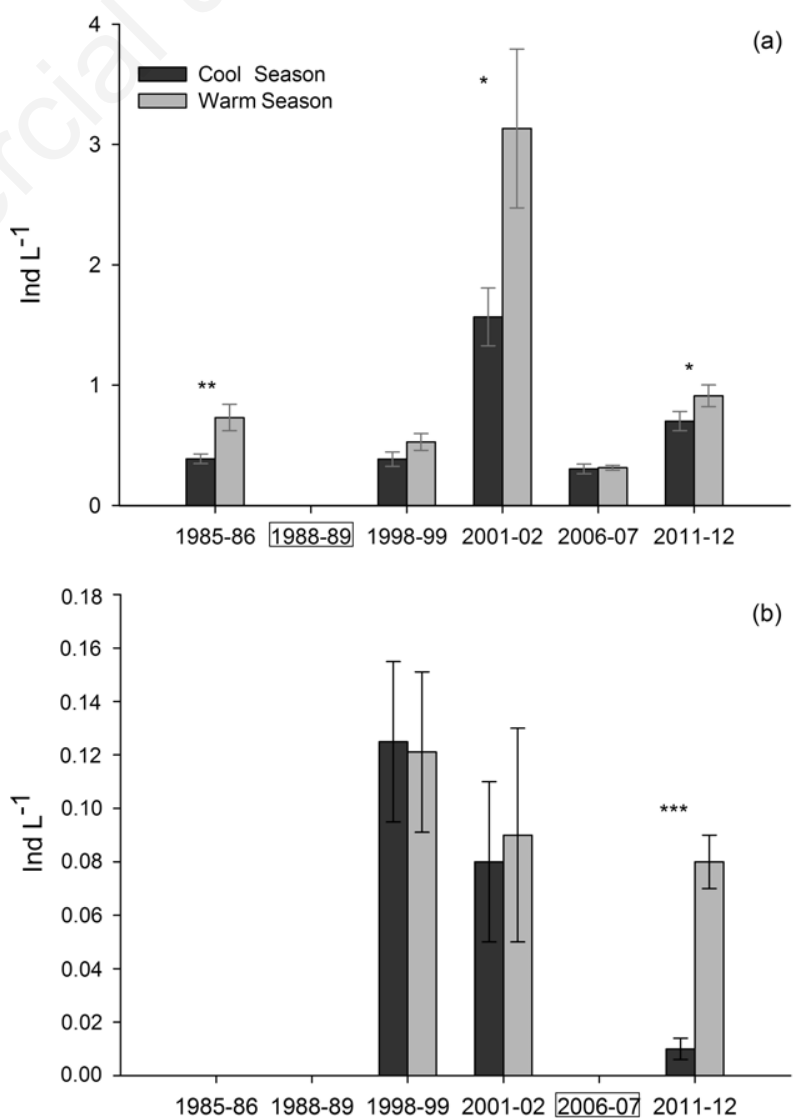

Fig. 7. Mean densities of chaoborid larvae (a) and mites (b) in the cool and warm seasons, in the different periods. Periods inside rectangles indicate that predators were present but were not counted. Significant differences between seasons: ${ }^{*} \mathrm{P}=0.05$; ${ }^{* *} \mathrm{P}=0.006 ;{ }^{* * *} \mathrm{P}=0.001$. 
planktivorous fish are abundant, and large-sized plankton when invertebrate predators predominate (Dodson, 1974), as summarized by Lampert and Sommer (2007; in Fig. 6.33). The decline in the contribution of smaller cladoceran species during and after the key period in Lake Monte Alegre reflects the greater influence of both invertebrate predators. Selective predation on smaller species or juveniles of larger species, related to the limitation imposed by the mouth size of Chaoborus larvae (Moore and Gilbert, 1987; Arcifa, 2000), influences the size composition of the community.

Not only can the size structure of the community respond to predation, but also the size structure within a population. The selection of larger phenotypes in some cladoceran populations can be a response to predation. Kerfoot (1974) reported that in a temperate lake, specimens of Bosmina longirostris (O. F. Müller) were larger in winter, when predation by fish decreased and the abundance of invertebrate predators (cyclopoids and chaoborids) increased. Bosmina can respond to changes in predation pressure by invertebrate predators with increasing size and change of some carapace structures, as reported in a review of paleolimnological studies (Korosi et al., 2013). In Lake Monte Alegre in 2011-12, the size of $B$. tubicen and D. ambigua was significantly larger in the warm season compared to the cool one, when Chaoborus larvae were more abundant (Souza, 2015). Carter et al. (2008) observed a smaller body size of $D$. ambigua exposed to kairomones from a mite species, indicating that the response to predators can vary according to their type and selectivity. Life-table parameters of various Daphnia species changed when the cladocerans were exposed to kairomones of different predators, such as Chaoborus, Notonecta and fish (review by Riessen, 1999); the size at first reproduction was slightly larger under the influence of Chaoborus kairomones, whereas it decreased when in contact with kairomones of the other two predators. Daphnia pulex can reach a larger size when exposed to kairomones of Chaoborus, by controlling the growth rate (Beckerman et al., 2010). Assuming that chaoborids induce an increase in the body size of prey and sucking predators (mites, notonectids) induce a decrease, the increase in body length of three cladoceran species in Lake Monte Alegre after the mite was detected could be a response to the most dominant predator, Chaoborus. A larger body size would be adaptive for the prey population to escape from at least one of the chaoborid instars. The increased body size of the small $B$. tubicen possibly prevented juveniles from being preyed on by the second instar of Chaoborus, which selects only immature individuals (Arcifa, 2000). Chaoborid larvae select only small juveniles of large species, such as Daphnia (Castilho-Noll and Arcifa, 2007a); although mites are able to prey on large specimens (Cassano et al., 2002), they seem to prefer small prey. We can hypothesise that even a small reduction in predation on Daphnia species due to a larger body size would be advantageous to the populations.

The trend towards greater abundance of Chaoborus in the warm season, and the presence of the mite, indicate that predation by both invertebrates is a key factor for the lower abundance of cladocerans in that season. The lack of a clear seasonal variation in copepod density through five periods is consistent with the smaller negative predator effects on them than on cladocerans. An increase in the abundance of Chaoborus larvae due to the introduction of piscivorous fish, which has caused changes in the fish fauna in Brazilian lakes, has driven the disappearance of cladocerans and the dominance of copepods in the lakes most heavily stocked by chaoborid larvae (PintoCoelho et al., 2008), giving support to our conclusion.

Predation by two limnetic invertebrates emerged in this study as a major force in structuring the plankton community in Lake Monte Alegre, on a macro scale, in the course of almost three decades. The impact of increased predation, detected in the key period, led to a predominance of large-sized cladocerans and the
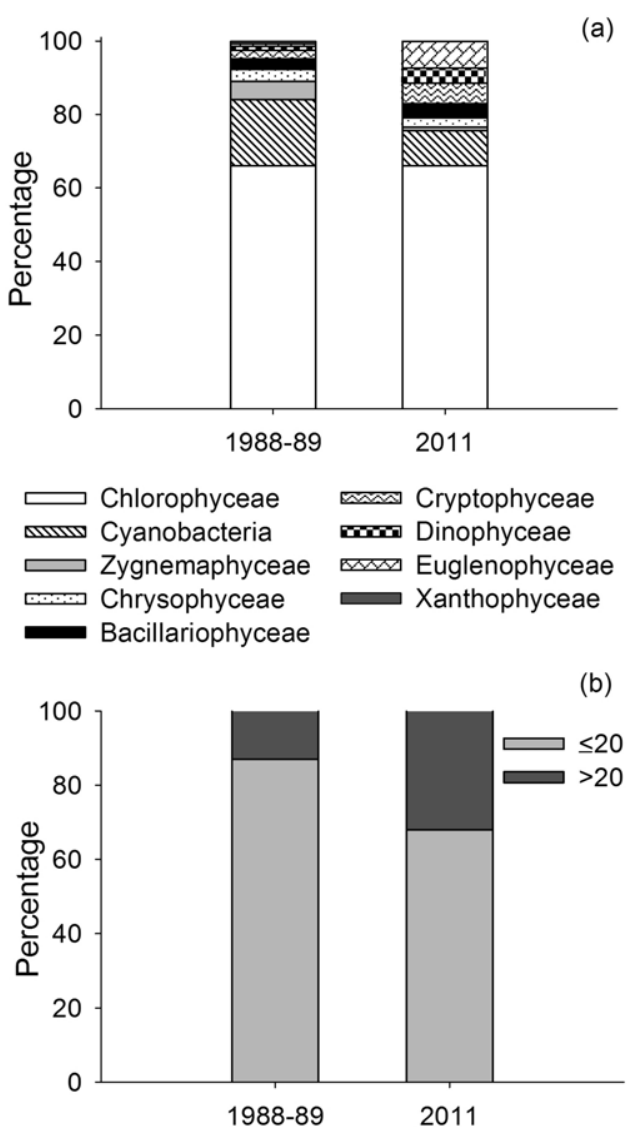

Fig. 8. Groups of phytoplankton (a) and size composition (b) in periods before and after the key period. Nanoplankton $(\leq 20$ $\mu \mathrm{m})$ and microplankton $(>20 \mu \mathrm{m})$. Source: Silva, 1995 (and unpublished data). 
disappearance of small species. A new structuring of species dominance, with a preponderance of copepods and a medium-sized $r$-strategist cladoceran (C. richardi), which is competitively superior to a larger species $(D$. gessneri) (Ferreira, 2013), was apparent in the last two periods. The success or recovery of some populations after the key period may be related to the ability to occupy also the littoral zone of the lake, where Chaoborus and mites are less abundant, as observed for B. tubicen (Arcifa et al., 2013; Souza, 2015). We presume that these areas are not permanent habitats, but serve to maintain a minimum population density and enable the reoccupation of the limnetic zone when conditions are more favourable, as we are observing for B. tubicen.

An invading species can affect the zooplankton community structure. An example is the predacious cladoceran Bythotrephes, which initially caused a decrease in the zooplankton diversity, but a long-term restructuring of the community eventually led to increased diversity (Kelly et al., 2013). Comparing Canadian and Norwegian lakes, the authors concluded that changes in species interactions, development of anti-predator strategies, and adaptation to the presence of predators have contributed to the increase of remnant populations, some decades after the Bythotrephes invasion. In Lake Monte Alegre, after a decade, a new structuring of the microcrustaceans' community has established the dominance of species that are less sensitive to predatory effects, i.e., that are less impacted by predation or have anti-predator strategies and higher reproductive rates.

The coincidence between low chlorophyll- $a$ concentrations and the highest densities of cladocerans, comparing all periods, ca. 58\% composed of a large-sized species, in 2006-07, suggests the control of phytoplankton by zooplankton. The restructuring of the microcrustacean community could theoretically be reflected in the phytoplankton through a top-down effect. Increased copepod dominance together with the predominance of large- and medium-sized cladocerans might lead to changes in the phytoplankton composition. The most abundant species of cyclopoid copepod, T. prasinus meridionalis, was successfully reared in the laboratory from nauplii to adult on a diet of seston $<20 \mu \mathrm{m}$ and cultured green algae Scenedesmus spinosus and Ankistrodesmus falcatus (Minto, 2009), suggesting that herbivory is its predominant habit. However, comparison of the phytoplankton biomass and composition in different periods, before and after the key period, indicates that the top-down effect on zooplankton does not cascade to the phytoplankton in the long-term.

\section{CONCLUSIONS AND FINAL REMARKS}

On a macro scale, over almost three decades of intermittent studies, predation by invertebrates was the predominant factor influencing the species composition and size structure of planktonic microcrustaceans in Lake Monte Alegre. The appearance of a second predator initially increased the pressure on the smaller cladoceran species, leading to the dominance of large- and mediumsized species in the long term. Before the mite appeared, predation by instars III and IV of Chaoborus, with mean densities of about 0.5 ind $\mathrm{L}^{-1}$ and a lower spatial overlap with prey, due also to the diurnal migration of the larvae to the sediment, allowed populations of smaller species to persist. The mite increased the predation pressure on microcrustaceans, especially on smaller species; its predation on Chaoborus has induced changes in the diel vertical migration of instar IV, increasing the impact of this instar on its prey.

The mite is usually not abundant, and its erratic and uncoordinated movements are not well adapted to planktonic life, in Lake Monte Alegre. Krendowskia sp. differs from other mite species that are more adapted to open waters, such as Piona limnetica Biesiadka (Gliwicz and Biesiadka, 1975). Even so, there was a combined effect of both predators, although the effect of mite predation is lower than that of the chaoborid larvae, as the prey responses seem to be more related to Chaoborus than to the impact of the mite.

Lampert and Sommer (2007) outlined the possible changes in the structure of the zooplankton community in response to predation. The situation in Lake Monte Alegre could be identified with their Fig. 6.33a, due to the absence of vertebrate visual predators and the presence of two invertebrate predators in the limnetic zone. Our longterm study showed that there was a period (key period) similar to the diagram of Fig. 6.33a, with a predominance of larger cladoceran species. Higher predation pressure from both predators clearly impacted the smaller species, leading to their virtual extinction in the limnetic zone. After a longer period, however, the community structure departed from the diagram of Lampert and Sommer, due to the increasing dominance of a medium-sized species.

This change in the microcrustacean composition, after the initial impact of a new predator, agrees with the observations of Kelly et al. (2013) and Yan et al. (2008), amongst other examples. Similarly to the Canadian lakes that they studied, a short-term impact, following the detection of the mite in Lake Monte Alegre, resulted in a marked decrease in species richness. In the long term, however, the species richness increased, as in the Norwegian lakes. This difference between the short- and longterm composition and size of the community indicates that a new equilibrium was reached after a longer period of coexistence with the new predator in the lake.

The difficulty of predicting the impact of a predator in the long term resides in the dynamic nature of zooplankton communities, which can adapt to the new conditions and the new predator, including species replacement. In addition, other factors in the ecosystem may influence the species differently, with opposing ef- 
fects, for example, predation inducing a smaller size range and competition tending to expand the size range (Quintana et al., 2015). To date, about 12 years after the greatest impact of the new predator (key period), we observe an increasing contribution of a medium-sized, $r$-strategist and competitively superior species (Ferreira, 2013), which can also inhabit the littoral zone of the lake where Chaoborus and mites are almost absent (Souza, 2015). At the same time, there has been a partial recovery of smallsized populations, such as Bosmina, and an increase in species richness, which is comparable to the pre-mite period. Successful behavioural strategies to reduce predation may have been selected, i.e., reducing the spatial overlap with the predominant predator (Souza, 2015), as well as increasing body size, which is apparently advantageous for decreasing Chaoborus predation. The ability of some species, such as B. tubicen, D. birgei and C. richardi, to occupy the littoral zone and also the uppermost layer of the water column, seems to provide protection against both invertebrate predators. In addition to prey strategies, the seasonal variation in predation pressure, with lower abundance of the predators, particularly Chaoborus, in the cool season, also provides a seasonal refuge for prey. The spatial refuge is also enlarged in the cool season when the entire water column is available, since dissolved oxygen is not limiting below $3-3.5 \mathrm{~m}$ as in the warm season. A thicker oxygenated layer allows more space for evading predators using certain strategies such as diel vertical migration (Perticarrari et al., 2003, 2004).

The classic trophic chain of many temperate lakes (piscivorous fish - planktivorous fish - zooplankton, planktivorous invertebrates - phytoplankton) (Carpenter et al., 1985) does not apply to Lake Monte Alegre or to most warm lakes. The main reason is that visual predators occur mainly in the littoral zone (Fernando, 1994; Arcifa and Northcote, 1997; Meschiatti and Arcifa, 2002; Agostinho et al., 2003; Teixeira-de Mello et al., 2009) and are omnivores (Lazzaro, 1997; Jeppesen et al., 2007; González-Bergonzoni et al., 2012), with some exceptions. Predation on invertebrate predators, namely Chaoborus larvae, is exerted by omnivorous rather than planktivorous fish, whereas mites are rarely preyed on by fish in the lake (Meschiatti and Arcifa, 2002). The trophic structure in the lake departs in some aspects from the conceptual model presented by Carpenter et al. (1985; Fig. 2) and can be roughly outlined as follows: piscivorous fish - omnivorous fish - invertebrate predators - zooplankton - phytoplankton. The control exerted by crustacean plankton on phytoplankton seems to be less efficient in this lake than in temperate systems, where the classic trophic chain and larger herbivorous microcrustaceans are established.

We can conclude that the structure of the crustacean community is better understood in long-term studies, although these are not always feasible. The value of this study is the large data set with support from several individual studies, and the possibility to extrapolate the find- ings to other lakes with similar basic characteristics, without the need of further local long-term studies.

\section{ACKNOWLEDGMENTS}

We thank all the people who have followed one another in the laboratory during our long study for their help in field work. We also thank A.J. Meschiatti for helping in preparation of data set, F.T. Mise and B.B. Souza for part of the statistical analyses, B.E. Rosso for the mite identification, and J.W. Reid for the linguistic improvement. Special thanks are due to the São Paulo State Foundation for Research (FAPESP) for providing financial support to M.S.A. (process 97/10407-6), as well as grants to graduate students and post-graduate researchers, which made possible several experimental projects. We also thank the Coordination for the Improvement of Higher Education Personnel (CAPES) for grants to graduate students and financial support provided through the Program for Graduate Students of the university, as well as two reviewers for their valuable suggestions.

\section{REFERENCES}

Agostinho AA, Gomes LC, Júlio Júnior HF. 2003. [Relações entre macrófitas aquáticas e fauna de peixes], p. 261-279. In: S.M. Thomaz and L.M. Bini (eds.), [Ecologia e manejo de macrófitas aquáticas].[Book in Portuguese]. EDUEM.

Alvares CA, Stape JL, Sentelhas PC, Gonçalves JLM, Sparovek G, 2013. Köppen's climate classification map for Brazil. Meteorol. Z. 22:711-728.

APHA, 1995. Standard methods for the examination of water and wastewater, $19^{\text {th }}$ ed. American Public Health Association, Washington: $1268 \mathrm{pp}$.

Arcifa MS, 1997. Fluctuations and vertical migration of Chaoborus in a tropical Brazilian reservoir: Lake Monte Alegre. Acta Limnol. Bras. 9:93-103.

Arcifa MS, 2000. Feeding habits of Chaoboridae larvae in a tropical Brazilian reservoir. Braz. J. Biol. 60:591-597.

Arcifa MS, Bunioto TC, Perticarrari A, Minto WJ, 2013. Diel horizontal distribution of microcrustaceans and predators throughout a year in a shallow neotropical lake. Braz. J. Biol. 73:103-114.

Arcifa MS, Gomes EAT, Meschiatti AJ, 1992. Composition and fluctuations of the zooplankton of a tropical Brazilian reservoir. Arch. Hydrobiol. 123:479-495.

Arcifa MS, Meschiatti AJ, 1993. Distribution and feeding ecology of fishes in a Brazilian reservoir: Lake Monte Alegre. Interciencia 18:302-313.

Arcifa MS, Meschiatti AJ, 1996. Tilapia rendalli in the Lake Monte Alegre, a case of planktivory. Acta Limnol. Bras. 8:221-229.

Arcifa MS, Meschiatti AJ, Gomes EAT, 1990. Thermal regime and stability of a tropical shallow reservoir: Lake Monte Alegre, Brazil. Rev. Hydrobiol. Trop. 23:271-281.

Arcifa MS, Northcote TG, 1997. Need for holistic approaches in food web experiments and biomanipulation in tropical lakes: a Brazilian reservoir experience. Verh. Internat. Verein. Limnol. 26:661-665.

Arcifa MS, Silva LHS, Silva MHL, 1998. The planktonic com- 
munity in a tropical Brazilian reservoir: composition, fluctuations and interactions. Braz. J. Biol. 58:241-254.

Balseiro EG, 1992. The role of pelagic water mites in the control of cladoceran population in a temperate lake of the southern Andes. J. Plankton Res. 14:1267-1277.

Beckerman AP, Rodgers GM, Dennis SR, 2010. The reaction norm of size and age at maturity under multiple predator risk. J. Anim. Ecol. 79:1069-1076.

Blumenshine SC, Hambright KD, 2003. Top-down control in pelagic systems: a role for invertebrate predation. Hydrobiologia 491:347-356.

Brooks JL, Dodson SI, 1965. Predation, body size, and composition of plankton. Science 150:28-35.

Bunioto TC, Arcifa MS, 2007. Effects of food limitation and temperature on cladocerans from a tropical Brazilian lake. Aquat. Ecol. 41:569-578.

Buskey EJ, Lenz PH, Hartline DK, 2012. Sensory perception, neurobiology, and behavioral adaptations for predator avoidance in planktonic copepods. Adapt. Behav. 20:57-66.

Carpenter SR, Kitchell JF, Hodgson JR, 1985. Cascading trophic interactions and lake productivity. BioScience 35 : 634-639.

Carter MJ, Vega-Retter C, Ramos-Jiliberto R, 2008. Non-lethal effects of invertebrate predators on Daphnia: morphological and life-history consequences of water mite kairomone. Freshwater Biol. 53:1857-1867.

Cassano CR, Castilho-Noll MSM, Arcifa MS, 2002. Water mite predation on zooplankton of a tropical lake. Braz. J. Biol. 62:565-571.

Castilho-Noll MSM, Arcifa MS, 2007a. Chaoborus diet in a tropical lake and predation of microcrustaceans in laboratory experiments. Acta Limnol. Bras. 19:163-174.

Castilho-Noll MSM, Arcifa MS, 2007b. Mesocosm experiment on the impact of invertebrate predation on zooplankton of a tropical lake. Aquat. Ecol. 41:587-598.

Cleto-Filho SEN, Arcifa MS, 2006. Horizontal distribution and temporal variation of the zoobenthos of a tropical Brazilian lake. Acta Limnol. Bras. 18:407-421.

Dodson SI, 1974. Zooplankton competition and predation: an experimental test of the size-efficiency hypothesis. Ecology 55:605-613.

Feresin EG, Arcifa MS, Silva LHS, Esguícero ALH, 2010. Primary productivity of the phytoplankton in a tropical Brazilian shallow lake: experiments in the lake and in mesocosms. Acta Limnol. Bras. 22:384-396.

Fernández HR, Fossati-Gaschignard O, 2011. An initial classification of neotropical water mites (Acari: Hydrachnidia) based on habitat preferences. Int. J. Ecol. doi:10.1155/2011/ 910540

Fernando CH, 1994. Zooplankton, fish and fisheries in tropical freshwaters. Hydrobiologia 272:105-123.

Ferrão-Filho AS, Arcifa MS, Fileto C, 2003. Resource limitation and food quality for cladocerans in a tropical Brazilian lake. Hydrobiologia 491:201-210.

Ferrão-Filho AS, Arcifa MS, Fileto C, 2005. Influence of seasonal variation of seston on growth of tropical cladocerans. Braz. J. Biol. 65:77-89.

Ferreira TCS, 2013. [Competição, predação e variação temporal de microcrustáceos planctônicos no Lago Monte Alegre].[Master Thesis in Portuguese]. University of São Paulo, Brazil.

Finlay K, Beisner BE, Pastoine A, Pinel-Alloul B, 2007. Re- gional ecosystem variability drives the relative importance of bottom-up and top-down factors for zooplankton size spectra. Can. J. Fish. Aquat. Sci. 64:516-529.

Gillooly JF, Dodson SI, 2000. Latitudinal patterns in the size distribution and seasonal dynamics of New World, freshwater cladocerans. Limnol. Oceanogr. 45:22-30.

Gliwicz ZM, Biesiadka E, 1975. Pelagic water mites (Hydracarina) and their effect on the plankton community in a neotropical man-made lake. Arch. Hydrobiol. 76:65-88.

González-Bergonzoni I, Meerhoff M, Davidson TA, Teixeira-de Mello F, Baattrup-Pedersen A, Jeppesen E, 2012. Metaanalysis shows a consistent and strong latitudinal pattern in fish omnivory across ecosystems. Ecosystems 15:492-503.

Hambright KD, 2008. Long-term zooplankton body size and species changes in a subtropical lake: implications for lake management. Fund. Appl. Limnol. 173:1-13.

Hart RC, Bychek EA, 2011. Body size in freshwater planktonic crustaceans: an overview of extrinsic determinants and modifying influences of biotic interactions. Hydrobiologia 668:61-108.

Havens KE, Pinto-Coelho RM, Beklioğlu M, Christoffersen KC, Jeppesen E, Lauridsen TL, Mazumder A, Méthot G, PinelAlloul B, Tavşanoğlu UN, Erdoğan S, Vijverberg J, 2015. Temperature effects on body size of freshwater crustacean zooplankton from Greenland to the tropics. Hydrobiologia 743:27-35.

Heuschele J, Selander E, 2014. The chemical ecology of copepods. J. Plankton Res. 36:895-913.

Iglesias C, Mazzeo N, Meerhoff M, Lacerot G, Clemente JM, Scasso F, Kruk C, Goynola G, García-Alonso J, Amsinck SL, Paggi JC, de Paggi SJ, Jeppesen E, 2011. High predation is of key importance for dominance of small-bodied zooplankton in warm shallow lakes: evidence from lakes, fish exclosures and surface sediments. Hydrobiologia 667:133-147.

Jackson JK, Füreder L, 2006. Long-term study of freshwater macroinvertebrates: a review of the frequency, duration and ecological significance. Freshwater Biol. 51:591-603.

Jäger IS, Hölker F, Flöder S, Walz N, 2011. Impact of Chaoborus flavicans-predation on the zooplankton in a mesotrophic lake - a three year study. Internat. Rev. Hydrobiol. 96:191-208.

Jeffrey SW, Humphrey GF, 1975. New spectrophotometric equations for determining chlorophylls $a, b, c_{1}$ and $c_{2}$ in higher plants, algae and natural phytoplankton. Biochem. Physiol. Pflanz. 167:191-194.

Jeppesen E, Christoffersen K, Landkildehus F, Lauridsen T, Amsinck SL, Riget F, Søndergaard M, 2001. Fish and crustaceans in northeast Greenland lakes with special emphasis on interactions between Arctic charr (Salvelinus alpinus), Lepidurus arcticus and benthic chydorids. Hydrobiologia 442:329-337.

Jeppesen E, Jensen JP, Jensen C, Bjørn F, Hessen DO, Søndergaard M, Lauridsen T, Brettum P, Christoffersen K, 2003. The impact of nutrient state and lake depth on top-down control in the pelagic zone of lakes: a study of 466 lakes from the temperate zone to the Arctic. Ecosystems 6:313-325.

Jeppesen E, Meerhoff M, Jakobsen BA, Hansen RS, Søndergaard M, Jensen JP, Lauridsen TL, Mazzeo N, Branco CWC, 2007. Restoration of shallow lakes by nutrient control and biomanipulation - the successful strategy varies with lake size and climate. Hydrobiologia 581:269-285.

Kelly NE, Yan ND, Walsen B, Hessen DO, 2013. Differential 
short- and long-term effects of an invertebrate predator on zooplankton communities in invaded and native lakes. Diversity Distr. 19:396-410.

Kerfoot CW, 1974. Egg-size cycle of a cladoceran. Ecology 55:1259-1270.

Kerfoot CW, Sih A, 1987. Predation: direct and indirect impacts on aquatic communities. University Press of New England, Hanover: 386 pp.

Korosi JB, Kurek J, Smol JP, 2013. A review on utilizing Bosmina size structure archived in lake sediments to infer historic shifts in predation regimes. J. Plankton Res. 35:444-460.

Lampert W, Sommer U, 2007. Limnoecology: the ecology of lakes and streams. $2^{\text {nd }}$ ed. Oxford University Press, Oxford: $324 \mathrm{pp}$.

Lazzaro X, 1997. Do the trophic cascade hypothesis and classical biomanipulation approaches apply to tropical lakes and reservoirs? Verh. Internat. Verein. Limnol. 26:719-730.

Liljendahl-Nurminen A, Horppila J, Malinen T, Eloranta P, Vinni M, Alajärvi E, Valtonen S, 2003. The supremacy of invertebrate predators over fish - factors behind the unconventional seasonal dynamics of cladocerans in Lake Hiidenvesi. Arch. Hydrobiol. 158:75-96.

Lorenzen CJ, 1967. Determination of chlorophyll and pheopigments: spectro-photometric equations. Limnol. Oceanogr. 12:343-346.

Maberly SC, Elliott JA, 2012. Insights from long-term studies in the Windermere catchment: external stressors, internal interactions and the structure and function of lake ecosystems. Freshwater Biol. 57:233-243.

Matveev VT, Martinez CC, Frutos SM, 1989. Predatory-prey relationships in subtropical zooplankton: water mite against cladocerans in an Argentine lake. Oecologia 79:489-495.

Meschiatti AJ, Arcifa MS, 2002. Early life stages of fish and the relationships with zooplankton in a tropical Brazilian reservoir: Lake Monte Alegre. Braz. J. Biol. 62:41-50.

Minto WJ, 2009. [Biomassa, densidade e produção secundária de microcrustáceos planctônicos no lago Monte Alegre]. [Ph.D. Thesis in Portuguese]. University of São Paulo, Brazil.

Minto WJ, Arcifa MS, Perticarrari A, 2010. Experiments on the influence of Chaoborus brasiliensis Theobald, 1901 (Diptera: Chaoboridae) on the diel vertical migration of microcrustaceans from Lake Monte Alegre, Brazil. Braz. J. Biol. 70:25-35.

Moore MV, Gilbert JJ, 1987. Age-specific Chaoborus predation on rotifer prey. Freshwater Biol. 17:223-236.

Nimer E, 1989. [Climatologia do Brasil]. $2^{\text {nd }}$ ed.[Book in Portuguese]. IBGE, Rio de Janeiro: $421 \mathrm{pp}$.

Perticarrari A, 2000. [Migração vertical de microcrustáceos, Chaoboridae e Hydracarina no Lago Monte Alegre].[Master Thesis in Portuguese]. University of São Paulo, Brazil.

Perticarrari A, Arcifa MS, Rodrigues RA, 2003. Diel vertical migration of cladocerans in a tropical lake. Nauplius 11:15-25.

Perticarrari A, Arcifa MS, Rodrigues RA, 2004. Diel vertical migration of copepods in a Brazilian lake: a mechanism for decreasing risk of Chaoborus predation? Braz. J. Biol. 64:289-298.

Pinto-Coelho RM, Bezerra-Neto JF, Miranda F, Mota TG, Resck R, Santos AM, Maia-Barbosa PM, Mello NAST, Marques MM, Campos MO, Barbosa FAR, 2008. The inverted trophic cascade in tropical plankton communities: impacts of exotic fish in the middle Rio Doce lake district, Minas
Gerais, Brazil. Braz. J. Biol. 68:1025-1037.

Quintana XD, Arim M, Badosa A, Blanco JM, Boix D, Brucet S, Compte J, Egozcue JJ, de Eyto E, Gaedke U, Gascón S, De Solá LG, Irvine K, Jeppesen E, Lauridsen TL, LópezFlores R, Mehner T, Romo S, Søndergaard M, 2015. Predation and competition effects on the size diversity of aquatic communities. Aquat. Sci. 77:45-57.

Riessen HP, 1982. Predatory behavior and prey selectivity of the pelagic water mite Piona constricta. Can. J. Fish. Aquat. Sci. 39:1569-1579.

Riessen HP, 1999. Predator-induced life history shifts in Daphnia: a synthesis of studies using meta-analysis. Can. J. Fish. Aquat. Sci. 56:2487-2494.

Saunders PA, Porter KG, Taylor BE, 1999. Population dynamics of Daphnia spp. and implications for trophic interactions in a small, monomictic lake. J. Plankton Res. 21:1823-1845.

Sih A, Englund G, Wooster D, 1998. Emergent impacts of multiple predators on prey. Tree 13:350-355.

Silva LHS, 1995. [Variabilidade temporal na estrutura da comunidade fitoplanctônica de um reservatório eutrófico - Lago Monte Alegre, Ribeirão Preto, São Paulo, Brasil].[Master Thesis in Portuguese]. Federal University of Rio de Janeiro, Brazil.

Silva LHS, Arcifa MS, Salazar-Torres G, Huszar VLM, 2014. Tilapia rendalli increases phytoplankton biomass of a shallow tropical lake. Acta Limnol. Bras. 26:429-441.

Souza BB, 2015. [Variação espacial e temporal de microcrustáceos planctônicos do lago Monte Alegre e experimentos abordando a influência da qualidade do alimento sobre o desempenho dos cladóceros].[Master Thesis in Portuguese]. University of São Paulo, Brazil.

Stegen JC, Black AR, 2011. Trophic ecology of an aquatic mite (Piona carnea) preying on Daphnia pulex: effects of predator density, nutrient supply and a second predator (Chaoborus americanus). Hydrobiologia 668:171-182.

Steiner CF, 2004. Daphnia dominance and zooplankton community structure in fishless ponds. J. Plankton Res. 26:799-810.

Strickler JR, 1975. Intra- and interspecific information flow among planktonic copepods: receptors. Verh. Internat. Verein. Limnol. 19:2951-2958.

Teixeira-de Mello F, Meerhoff M, Pekcan-Hekim Z, Jeppesen E, 2009. Substantial differences in littoral fish community structure and dynamics in subtropical and temperate shallow lakes. Freshwater Biol. 54:1202-1215.

Uehlinger V, 1964. [Étude statistique des méthodes de dénobrement planctonique].[Article in French]. Arch. Sci. 17:121-123.

Utermöhl V, 1958. [Zur Vervollkommung der quantitativen Phytoplankton-Methodik].[Article in German]. Mitt. int. Ver. theor. angew. Limnol. 9:1-38.

Vijverberger J, Dejen E, Getahun A, Nagelkerke LAJ, 2014. Zooplankton, fish communities and the role of planktivory in nine Ethiopian lakes. Hydrobiologia 722:45-60.

Yan ND, Somers KM, Girard RE, Paterson AM, Keller W, Ramcharan CW, Rusak JA, Ingram R, Morgan GE, Gunn JM, 2008. Long-term trends in zooplankton of Dorset, Ontario, lakes: the probable interactive effects of changes in $\mathrm{pH}$, total phosphorus, dissolved organic carbon, and predators. Can. J. Fish. Aquat. Sci. 65:862-877.

Zaret TM, 1980. Predation and freshwater communities. Yale University Press, New Haven: 187 pp. 